\title{
The Role of Government Schools in Creative Education of Students in the State of Kuwait
}

\author{
Mohammad Sayel Alzyoud ${ }^{1}$, Eman Saad Al-Heifi², Bilal Mohammad Salah Suleiman ${ }^{3}$ \& Ali Salem Al Ali ${ }^{4}$ \\ ${ }^{1}$ Associate Professor of Educational Foundations, School of Education, The University of Jordan, Amman, \\ Jordan \\ ${ }^{2}$ The Ministry of Education, The State of Kuwait, Kuwait \\ ${ }^{3}$ Assistant Profess or ofChildhood Education, School of Education, Al Balqa Applied Univ ersity, Assault, Jordan \\ ${ }^{4}$ Ass ociate Profes sor of Linguistics, School of Foreign Languages, The University of Jordan, Amman, Jordan \\ Correspondence: Mohammad Sayel Alzyoud, Associate Professor of Educational Foundations, School of \\ Education, The University of Jordan, Amman, Jordan. E-mail: Mohammad.alzyoud@outlook.com
}

\author{
Received: June 6, 2018 \\ Accepted: June 15, 2018 \\ Online Published: July 26, 2018 \\ doi:10.5539/mas.v12n8p 129 \\ URL: https://doi.org/10.5539/mas.v12n8p 129
}

\begin{abstract}
This paper focuses on identifying the role of government schools in creative education of students from the point of view of primary school teachers in the State of Kuwait. It also aims at finding the difference in the role of the school in the creative education of students due to the variables of experience, qualification, and specialization. The sample of the study consisted of 265 teachers from the primary government schools selected by random stratified method. A questionnaire was developed and its validity and reliability was verified. The questionnaire consisted of 45 items distributed over 5 themes; the administration, teachers, curriculum, school building, community, and parents. The results of the study showed that the role of schools in the creative education of students from the point of view of primary school teachers in government schools in the State of Kuwait was moderate. The results showed no statistically significant differences at the level $(\alpha=00.05)$ due to years of experience, qualifications, and specialization in all themes. In the light of the results of the study, several recommendations were made to improve the role of primary school in the creative education of students.
\end{abstract}

Keywor ds: creative education, Kuwait, school

\section{Introduction}

Creativity is one of the important educational goals that educational societies aspire to achieve. It is considered the supreme human language, which is mature. Although it is innate, an individual is not born creative but is born with seeds of creativity within him. In fact, the process of creativity is the outcome of meeting a set of factors or criteria. It has to do with the highest mental functions adequacy and more emotional qualities in the creative person. However, the best climate suitable for creative thinking can be experienced as we look at the guidance of the Prophet, peace be upon him, in developing the creativity of Companions (Abdul, 2006).

As innovation today is a secret of success and excellence in various themes, it enables the own er of the detection and invention of new ways and means to seek change and development. This is done in light of the fact that evolution has become a prerequisite and it generates the ability to deal with new situations, especially unfamiliar ones. In addition, it helps to discover the relationships that link different information. New ways to interact with quick variables make the most of the tools and ideas available (Almshrfe, 2005).

If innovation is a requirement in all social institutions, it is therefore necessary to start with the educational institutions represented by the schools, which are responsible for raising and educating the members of the society. This would make them effective members who contribute to the development of their society, and also help them to find solutions to the problems they may face in the future. It is logical for students to demand creativity. Hence, the teacher is at loss if he is unable to help the students to become creative and excellent. This, however, explains the futility of traditional education.

Although there is some care for creativity in some Arab countries, this care is still limited and insufficient to reach the care required to provide creativity. Thus, this gives us optimism about the transition from traditional 
schools to effective schools. Here, the student finds appropriate care for his abilities and contributes effectively in caring for creative and talented people (Bovetin, 2012).

The creative education works on self-realization and is based on the development of individual talents and improvement of human growth. Creators contribute to the productivity of the entire society culturally, economically, and scientifically. Creativity is one of the educational goals. In view of this, it is clear how important creative education is, and how it is directed towards the goal that educational processes seek to achieve, namely: creating and forming a creative human being capable of meeting the challenges of the times (Ajez \& Sheldan, 2010). Therefore, this study aims to identify the status of creative education in the Kuwaiti government schools in Farwaniya Governorate from the point of view of the primary school teachers and their perceptions of their development.

\section{Research Problem}

The theme of education is witnessing an advanced scientific renaissance that affected all aspects of education. The role of the school is been developed according to various international developments and is no longer confined to the process of reducing information. However, it has risen to the level of attention to various aspects that are directly related to personality (individual personality) to be able to learn and create. It is clear that modern schools seek to achieve the integrated development of the personality of the individual from the cognitive and emotional aspects and skills. Therefore, teaching individuals how to be creative is the importance of creative education by teachers to help students reach the degrees of creativity in various themes. This is because basic education is the basic room in the discovery of creativity and development. Therefore, it seeks attention and should be applied at the primary stage. This study answers the following questions:

Question 1: What is the role of the government schools in creative education of students from the point of view of primary school teachers in the State of Kuwait?

Question 2: Are there statistical significant differences $(\alpha \leq 0.05)$ in the role of the government schools in creative education of students from the point of view of primary school teachers in the State of Kuwait due to teacher's experience, qualification, and specialization?

\section{Importance of the Study}

The importance of the current study is to reveal the role of schools in creative education for students from the point of view of primary school teachers in government schools in Kuwait. It also helps to reveal the statistical significant differences $(\alpha \leq 0.05)$ in the role of schools in creative education of students from the point of view of primary school teachers in Kuwaiti government schools due to experience, qualification, and specialization for female teachers.

\section{Objectives of the Study}

The study sought to achieve the following objectives:

- To identify the role of schools in creative education of students from the point of view of primary schoolteachers in Kuwaiti government schools.

- To reveal the statistical significant differences $(\alpha \leq 0.05)$ in the role of the government schools in creative education of students from the point of view of primary school teachers in the State of Kuwait due to experience, qualification, and specialization for female teachers.

\section{Study Terminologies}

Creative Education: This is the education that encourages learners to think analytically about their own learn ing processes, combining global and local factors in the learning processes, and providing general and specific strategies for a wide variety of learning environ ments. Thus, learners may be able to take greater control of their own thinking and learning in various aspects (Rojanapanich \& Pimpa, 2011, p. 103).

Kuwait Government Schools: The schools that funded and operated the Ministry of Education in the State of Kuwait.

Primary School Teachers: Teachers who teach primary school students aged 4-11 years old in Kuwait government schools.

\section{Limitations of the Study}

The study is subject to the following limitations:

- Location Limitations: The study was applied in government schools in Farwaniya Governorate in Kuwait. 
- Time Limitations: The study was conducted in the first semester of 2016/2017.

- Human Limitations: This study was applied to female primary school teachers working in government schools in Farwaniya Governorate in Kuwait.

\section{Previous Related Studies}

The study revealed some studies related to creative education as follows:

Asaf (2013) conducted a study aimed at identifying the attitudes of social studies teachers towards developing the skills of creative thinking among the students of the upper elementary stage in the Directorate of Third Amman Education and its relation to the variables of scientific qualification and experience. A random sample of 133 teachers was selected in order to identify the following: teachers' attitudes toward developing creative thinking abilities, teachers' attitudes towards the detection and identification of creative skills, and teachers' attitudes towards encouraging and adopting creativity. The study found that teachers who follow the trend with a view of developing the creative thinking skills of the students are positive. This is with significant differences in the attitudes of the teachers towards developing the creative thinking skills of the students due to the variable of the academic qualification and the holders of the postgraduate certificate. There are no statistically significant differences in the teachers due to the variable of experience.

Trifonova (2012) conducted a study aimed at introducing an innovative educational approach through the design of the game of scenarios by teachers and participation in creative teaching practices, as well as training workshops. The study sample consisted of 21 teachers, including teachers from 7 primary and secondary schools in Spain. In order to achieve the objectives of the study, teachers were trained to design teaching scenarios and put them into practice in teaching contexts. The main results showed that teaching processes that involve the design of lessons electronically by teachers contributes to the development of creativity among students, which was seen as an incentive for teachers and students. The results also revealed the obstacles that hinder the student to develop his creativity. The method of designing the lessons electronically by the teachers and their application by the students contribute to support the creative and creative learning environment.

Robina (2010) conducted a study aimed at identify ing the capacity of the education system in Pakistan to promote creativity for children. The study sample consisted of 154 children who took the Torrance creative thinking tests. To achieve the objectives of the study, the classrooms were monitored in 16 elementary schools on a documentary analys is of educational policy documents, curricula, and textbooks. The main findings are that children could produce ideas, but appears to be weaker in other themes. This is attributed to the fact that the attitudes of teaching in Pakistan are aimed towards acquiring knowledge only, which has contributed to discouraging creativity. The results also found obstacles to the promotion of creat ivity related to the teacher who resort to traditional methods of teaching, and obstacles that are related to the curriculum. The study showed the need to involve parents in developing the curriculum since the educational system is permanent.

Ozmen and Muratoglu (2010) conducted a study in Turkey aimed at identify ing the creative competencies of school principals, particularly in the theme of knowledge, application, and management strategies. The study sample consisted of 214 principals and teachers, including 100 principals and teachers who responded to a questionnaire specially designed to achieve the study objective. The study showed that the most important creative competencies that the manager must possess are: effective knowledge management, the format ion of social support networks, and organizational and management competencies. The study showed that there are no statistically significant differences between males and females based on perceptions about the nature of creative competencies that must be possessed by the school principal.

Huwailah and Huwaila (2009) conducted a study in the State of Kuwait aimed at revealing the degree of practice of principals in the Ahmadi educational district based on the behaviors of achieving Admin istration innovation. The sample consisted of 66 principals in addition to a random sample of 208 teachers, and the researchers used a questionnaire consisting of 23 items. The results of the study showed that the degree of practice of principals of secondary schools in the Ahmadi educational system of Administration and creativity behaviors are a moderate ass essment from the point of view of teachers. However, from the results of the study, there were no statistically significant differences in the responses of managers by the variables of educational qualification and experience, and in the teachers' responses by sex and transgender experience. Also, there is existence of significant differences by variable educational qualification for the benefit of bachelor degree or higher degree.

Enezi (2008) conducted a study in Saudi Arabia aimed at revealing the level of Administration creativity of the principals in the north of Saudi Arabia from the point of view of teachers and educational supervisors. The sample consisted of 536 teachers and educational supervisors randomly selected. The study showed that the level 
of Administration innovation among school principals was moderate from the point of view of educational supervisors. On the other hand, it plays a strong role from the point of view of teachers. The results also showed that there are statistically significant differences due to the impact of educational function in all themes. Also, there was the existence of significant differences between the category of Master's degree and the categories of diplo ma and bachelor degree. However, more were in favor of the categories of diploma and bachelor degree in the themes of fluency and originality. There was also existence of significant differences between the category of bachelor degree and the category of Master's degree in the theme of sensitivity to problems.

Sharari (2008) also conducted a study in Saudi Arabia aimed at revealing the role of the principals in the development of creativity among teachers in Al-Jouf region in Saudi Arabia from the point of view of the teachers. The study found that the role of school principals in developing the creativity of teachers in the theme of social relations, management, expression, dialogue, and discussion played a very significant role. It also shows that the role of principals in developing creativity among teachers in the practical theme of Faculty was also paramount, as well as the improvement and development of the school environment. The study found out that there are significant statistical differences for the role of school principals in the development of creativity among teachers due to the variable sex in favor of females and years of experience.

Yahyaoui (2007) conducted a study in the Kingdom of Saudi Arabia aimed at identifying the Administration creativity in the government secondary schools for girls in Madinah in terms of the availability of the elements of creativity among the managers, the extent of their practice of Admin istration innovation, and the expected obstacles to their practice of Admin istration innovation. The study aimed at identifying the views of principals and teachers on the availability of creativity components of the principals. Also, the sample of the study of all members of the original community consisted of 111 directors and agents, and 1,185 teachers.

Wfry (2006) conducted a theme study in the United States that examined the relationship between the level of organizational creativity of the A merican school principal and effective learning. The study also aims to describe the indicators of quality communication and dialogue between the principal and individuals during creative processes, and its impact on the learning process. The results of the study were derived from a series of theme studies that were conducted on 13 school projects in 13 A merican schools. The researchers relied on the method of the interview, in which they deliberately interviewed 8-12 individuals in each project, including a director. Consequently, key variables included the following: Leadership, process characteristics, nature of decision making, level of participation, performance measurement criteria, sequence of learning process, learn ing about the organization, and appropriate organizational conditions for applying the learning type. The study found the following results: On the quality of learning processes in the organization, the role of the leader in educating and training individuals on the right communication methods, and raising the level of participation in decision-making processes, to unify the goals and trends among individuals have a significant influence on the learning process. As a result of the learning process, the above factors increase the creativity of individuals as well as the effectiveness of applying creative ideas.

Kandemir and Gur (2006) conducted a study aimed at surveying, observing, and discussing some of the diffe rent views of mathematics teachers in improving creative thinking through problem solving. The study sample consisted of 43 teachers. To achieve the objectives of the study, the results indicated that there is a shortage of courses and training programs based on the training of problem-solving methods. Hence, this reduces the enhancement of creativity. This is in addition to the low level of current teaching methods, which requires redesigning curricula according to creative teaching methods.

Subaihi (2006) conducted a study aimed to identify the main obstacles facing the study population and that negatively affects their creativity. The study also aims to identify the vulnerability of each of these constraints on artistic creation process with the teacher. The researcher selected a random sample of the study population consisting of 65 teachers, which relied on a descriptive and analytical approach. Therefore, highlighting the results showed the existence of obstacles in the development of creativity, including obstacles that are related to the teacher, as well as external constraints. It does not provide the right atmosphere for the creativity of the teacher and in assigning the teacher additional work outside the scope of specialization and obstacles to creativity such as, Repetition of ideas, similarity, and inability to develop.

Diab (2005) conducted a study aimed at identifying the most important obstacles to the development of creativity among the students of the basic stage in the schools of the Gaza Strip from the point of view of their teachers. The study was applied to a sample of 100 teachers. To achieve the objectives of the study, the results of the study showed that the level of obstacles that hinder the development of creativity among the students of the basic stage in the schools of the Gaza Strip is as a result of the lack of an interesting and encouraging school 
environment. Furthermore, it is also attributed to the lack of interest of the school administration in research, exploration, and discovery. This is also in addition to the lack of training courses for the teacher related to development Creativity, and lack of familiarity with the teacher strategies to develop creative thinking.

Sharari (2005) conducted a study aimed at identifying the obstacles to creativity in a sample of secondary school teachers in Al-Jouf region in Saudi Arabia. The study sample consisted of 500 teachers. To achieve the objectives of the study, the results of the study indicated that there is no exceptional system for the promotion of the creative teacher and the lack of financial resources. The study also found that there are statistically significant differences between male and female teachers in favor of males. Therefore, this is in addition to the fact that there are no differences due to scientific qualification and years of experience.

\subsection{Study Population}

The study population consists of 4,375 teachers in 48 government schools of the elementary stage in Al-Farwaniya Governorate in the State of Kuwait for the academic year (2017/2018).

\subsection{Study Sample}

The study sample consisted of 265 teachers from the total study population. The sample was chosen according to the stratified random approach. A total of 365 questionnaires were distributed to the sample of the study, and 265 $(88.3 \%)$ were retrieved. Table 1 shows the distribution of the sample size according to the study variables.

Table 1. The distribution of the study sample according to years of experience, qualification and specialization

\begin{tabular}{llll}
\hline Variables & Categories & Number & Percentage \\
\hline Years of experience & $(1-5)$ Years & 37 & $14 \%$ \\
& $(6-10)$ Years & 86 & $32 \%$ \\
& $(11-15)$ Years & 91 & $34 \%$ \\
Total & More than 15 Years & 51 & $20 \%$ \\
Qualification & & 265 & $100 \%$ \\
& Bachelor & 151 & $57 \%$ \\
\multirow{2}{*}{ Specialization } & Postgraduate & 114 & $43 \%$ \\
& Total & 265 & $100 \%$ \\
Total & Literary & 168 & $64 \%$ \\
\hline
\end{tabular}

\subsection{The Questionnaire}

To achieve the objectives of the study, the study questionnaire was constructed in light of educational literature that was related to the subject of the study. The questionnaire consisted of 45 items which covered five themes, namely; admin istrative, teachers, curriculum, school building, parents, and community. It is determined by the five-point Likert scale (Very Strong, Strong, Moderate, Poor, and Very Poor) and values (5, 4, 3, 2, 1), respectively.

\subsection{The Questionnaire Validity}

The questionnaire validity was verified by presenting it to 10 professors of the educational admin istration, the educational foundations, curriculum, teaching and educational technology from the University of Jordan, Kuwait University, and the Jordanian Ministry of Education. The professors were asked to revise and review the questionnaire in terms of clarity of items and the language and degree of belonging to the theme of the questionnaire. It also modifies or deletes any item that does not achieve the objective of the study. The questionnaire was revised and amended based on the professors'comments and suggestions.

\subsection{The Questionnaire Reliability}

The questionnaire reliability was measured using the internal consistency method according to the Cronbach's Alpha, as shown in Table 2.

Table 2. The Cronbach's Alpha consistency coefficient values for all study themes 


\begin{tabular}{lll}
\hline No & Theme & Internal Consistency \\
\hline 1 & Administration & 0.86 \\
2 & Teachers & 0.89 \\
3 & Curriculum & 0.93 \\
4 & School building & 0.90 \\
5 & Parents and community & 0.91 \\
\hline
\end{tabular}

Table 2 showed that all the values of the coefficient of reliability (The Cronbach's alpha) for the themes of the study questionnaire ranged between $86 \%-93 \%$. These results were acceptable for the study purpose.

\section{Statistical Analysis}

The Statistical Package for Social Sciences (SPSS) was used to answer the study questions. In answering the first and second questions, the mean and the standard deviations were used. In answering the third question, mean, standard deviations, and the multiple analysis of variance (MANOVA) was performed. To determine the school role, the study adopted the mean of the responses of the sample members based on manual scoring to obtain the division of scores $(5-1=4 \div 3=1.33+1=2.33)$. The range of criteria based on a five point Likert scale was given as: $1-2.33=$ Weak, $2.34-3.66=$ Moderate, $3.67-5=$ strong.

\section{Results and Discussion}

The results of the study were arranged according to the study questions. Question one states "What is the role of the government schools in creative education of students from the point of $v$ iew of primary school teachers in the State of Kuwait?"

To answer this question, the mean, rank, and standard deviations of the role of the school in creative education of students were analysed, as shown in Table 3.

Table 3. Mean, standard deviations, rank and the role of schools in creative education of students from the point of view of primary school teachers in the government schools in the State of Kuwait

\begin{tabular}{llllll}
\hline $\begin{array}{l}\text { Ite m } \\
\text { No. }\end{array}$ & Rank & Themes & Mean & S. D & School Role \\
\hline 2 & 1 & Teachers & 3.95 & 0.70 & Strong \\
1 & 2 & Curriculum & 3.61 & 0.87 & Moderate \\
4 & 3 & School building & 3.58 & 0.91 & Moderate \\
3 & 4 & Administration & 3.50 & 0.69 & Moderate \\
5 & 5 & Parents and community & 3.14 & 0.96 & Moderate \\
\hline
\end{tabular}

Table 3 shows that the mean of the school role in the creative education of students from the point of view of primary school teachers in government schools in the State of Kuwait as a whole was 3.57, with a standard deviation of 0.68 , and with a moderate role. This refers to the fact that schools have to deal with the daily routine work, cover up the curriculum, as well as carry out some administration and paper work. There fore, they do not have enough time to concentrate on creative education and its aspects. All school elements focus on the regular daily work and there are no real planned activities on creative education. The mean of all themes ranged between 3.14 - 3.95. The theme of teachers came first with the highest mean of 3.95, with a standard deviation of 0.70 and a strong role. This refers to the fact that teachers do their best in creative education through the different teaching activities. The curriculum theme scored a mean of 3.61, with a standard deviation of 0.87 and a moderate role; followed by the theme of school building with a mean of 3.58 and a standard deviation 0.91; followed by the Admin istration theme with a mean of 3.50, a standard deviation of 0.69 and moderate role; while the theme of parents and community came in the last place with a mean of 3.15 , a standard deviation of 0.96 , and a moderate role. The three themes achieved moderate role due to the fact that schools have limited services and resources that can be utilized to support creative education activities. In addition, all concerned parties except teachers have supportive role to creative education. Thus, it is still not sufficient enough from the teachers' point of view. School principals have multiple tasks and do not have enough time to communicate effectively with parents and community institutions, and their greater attention is directed to the educational process rather than to creative education requirements. Parents as well have moderate role in supporting creative education. This is because most parents are preoccupied with government and military jobs which are far from their homes, which makes communication between parents and school very weak. In general, parents are less aware of the 
importance of creative education or even giving the required support to their children. Most parents visit and follow up their children only when major problem happened.

The detailed results of the teachers' theme are presented in Table 4 as follows:

Table 4. Mean, standard deviations, rank and school role

\begin{tabular}{|c|c|c|c|c|c|}
\hline Rank & No. & Items & Mean & S.D. & $\begin{array}{l}\text { School } \\
\text { Role }\end{array}$ \\
\hline 1 & 18 & $\begin{array}{l}\text { The teacher takes into consideration individual } \\
\text { differences among students. }\end{array}$ & 4.45 & 0.92 & Strong \\
\hline 2 & 11 & $\begin{array}{l}\text { The teacher performs the work entrusted to } \\
\text { him/her in a professionalmanner. }\end{array}$ & 4.37 & 0.92 & Strong \\
\hline 3 & 15 & $\begin{array}{l}\text { The teacher provides learning resources that help } \\
\text { in creative teaching. }\end{array}$ & 4.36 & 0.98 & Strong \\
\hline 3 & 14 & $\begin{array}{l}\text { The teacher develops training programs on } \\
\text { teaching creative thinking skills. }\end{array}$ & 4.36 & 0.99 & Strong \\
\hline 5 & 17 & $\begin{array}{l}\text { The teacher provides training and activities to } \\
\text { solve scientific problems. }\end{array}$ & 4.26 & 0.92 & Strong \\
\hline 6 & 19 & $\begin{array}{l}\text { The teacher uses innovative strategies that } \\
\text { stimulate creativity. }\end{array}$ & 4.12 & 0.92 & Strong \\
\hline 7 & 13 & $\begin{array}{l}\text { The teacher applies the theoretical aspects in the } \\
\text { creative application. }\end{array}$ & 4.01 & 0.98 & Strong \\
\hline 8 & 16 & $\begin{array}{l}\text { The teacher depends on the method of dialogue, } \\
\text { persuasion and respect for the otheropinion. }\end{array}$ & 3.58 & 1.12 & Moderate \\
\hline 9 & 20 & The Teachers stimulate the gifted student. & 3.51 & 1.46 & Moderate \\
\hline 10 & 12 & $\begin{array}{l}\text { The teacher applies new methods to solve the } \\
\text { problems that they face. }\end{array}$ & 3.46 & 1.15 & Moderate \\
\hline Overall & & & 3.95 & 0.70 & Strong \\
\hline
\end{tabular}

Table 4 shows that the mean of the teachers' theme as a whole was 3.95 , with a standard deviation of 0.70 , and with a strong role. The mean of the items ranged between 3.46 and 4.45. Item 18 that stated "The teacher takes into consideration individual differences among students" scored a mean of 4.45 and a standard deviation of 0.92 with a strong school role. This is referred to as the basic role of the teachers and it takes into consideration the individual differences not only to promote creative education, but also as one of their basic duties toward their students.

Item 11 that stated "The teacher performs the work entrusted to him/her in a pro fessional manner" ranked second with a strong role, a mean of 4.37 , and a standard deviation of 0.92 . Item 15 that stated "The teacher provides learning sources that help in creative teaching" ranked third with mean score of 4.36 , standard deviation of 0.98 , and strong role. This is referred to the fact that teachers receive professional training on creative education and critical thinking skills. Therefore, they concentrate on creative education "with a moderate of 4.36." The teacher provides training and activities to solve scientific problems "with a moderate of 4.26." The teacher also uses innovative strategies to stimulate creativity "with a moderate of 4.12." Thus, the teacher applies the theoretical aspects in the application of creativity. Furthermore, the study is based on these reports, which are evaluated on the basis of what the teacher and the educational supervis or evaluated.

Items 16 that stated "The teacher depends on the method of dialogue, persuasion and respect for the other opinion" scored a mean of 3.58 and standard deviation of 1.12 with a moderate role. Item 20 that stated "The teachers stimulate gifted and creative students" scored a mean of 3.46 and standard deviation of 1.46 with a moderate role. Item 12 that stated "The teacher applies new methods to solve the problems that they face" scored a mean of 3.46 and a standard deviation of 1.15 with a moderate role. This is referred to the fact that teachers still lack the skills needed to motivate the creativity of the learners as well as to follow the traditional teaching approaches and methods.

The detailed results of the curriculum theme are presented in Table 5 as follows:

Table 5. Mean, standard deviations, rank and schoolrole

\begin{tabular}{llllll}
\hline No. & Rank & Items & Mean & S.D. & Role \\
\hline
\end{tabular}




\begin{tabular}{|c|c|c|c|c|c|}
\hline 24 & 1 & $\begin{array}{l}\text { The curriculum connects the learner to the } \\
\text { surrounding environment. }\end{array}$ & 4.03 & 0.98 & Strong \\
\hline 22 & 2 & Creative activities are available in the curriculum. & 3.92 & 0.98 & Strong \\
\hline 21 & 3 & $\begin{array}{l}\text { The way the curriculum is structured fits into the } \\
\text { teaching of creative thinking skills. }\end{array}$ & 3.90 & 1.03 & Strong \\
\hline 26 & 4 & $\begin{array}{l}\text { The curriculum contains life situations that need to } \\
\text { be taught }\end{array}$ & 3.74 & 1.07 & Strong \\
\hline 28 & 5 & $\begin{array}{l}\text { The curriculum promotes the efforts of scientists, } \\
\text { detectives and inventors. }\end{array}$ & 3.62 & 1.66 & Moderate \\
\hline 25 & 6 & $\begin{array}{l}\text { The curriculum develops creative abilities and } \\
\text { talents. }\end{array}$ & 3.48 & 1.20 & Moderate \\
\hline 23 & 7 & $\begin{array}{l}\text { The curriculum develops entrepreneurship and } \\
\text { experimentation. }\end{array}$ & 3.38 & 1.11 & Moderate \\
\hline 29 & 8 & $\begin{array}{l}\text { Curriculum evaluations focus on higher thinking } \\
\text { skills (analysis, application, criticism, creativity) }\end{array}$ & 3.31 & 1.10 & Moderate \\
\hline 27 & 9 & $\begin{array}{l}\text { The curriculum contains scientific achievements } \\
\text { and discoveries. }\end{array}$ & 3.14 & 1.15 & Moderate \\
\hline \multicolumn{3}{|c|}{ Overall } & 3.61 & 0.87 & Moderate \\
\hline
\end{tabular}

Table 5 shows that the mean of the whole curriculum theme was 3.61, with a standard deviation of 0.87 , and with a moderate role. This is referred to the fact that the national curriculum still needs imp rovement in order to meet the creative education requirements and standards. The curriculum contains some activities that support creative education, but it needs more improvement and enrichment in areas related to creative education.

Item 24 that stated "The curriculum connects the learner to the surrounding environment" scored a mean of 4.03 and a standard deviation of 0.98 with a moderate role. This referred to the nature of the school curriculum that was built for the State of Kuwait and its environment and traditions. Therefore, the State of Kuwait follows a national curriculum that is especially designed for its students.

Item 22 that stated "Creative activities are available in the curriculum" scored a mean of 3.92 and standard deviation of 0.98 , with a strong role. The Kuwaiti National Curriculum contains some activities that promote creative education. As a result, teachers considered this a strong aspect that supports the school role in creative education activities.

Items 27 that stated "The curriculum contains scientific achievements and discoveries" scored a mean of 3.14 and a standard deviation of 1.15 with a moderate role. This is referred to the fact that the curriculum is poor and does not possess enough information, activities about scientific achievements and discoveries.

Item 29 that stated "Curriculum evaluations focus on higher thinking skills (analysis, application, critic is m, creativity)" scored a mean of 3.31 and standard deviation of 1.10, with a moderate role. This is referred to the current structures of the Kuwaiti National Curricula that have limited focus on the high thinking skills. Thus, this is in addition to the traditional teaching methods that teachers adopt in the delivery of curricula.

The detailed results of school building theme are presented in Table 7. To answer the items in this theme, mean, standard deviations and rank were used for the subject theme of the curriculum.

Table 7. Mean, standard deviations, rank and school role

\begin{tabular}{|c|c|c|c|c|c|}
\hline No. & Rank & Items & Mean & S.D. & $\begin{array}{l}\text { School } \\
\text { Role }\end{array}$ \\
\hline 30 & 1 & $\begin{array}{l}\text { School building facilitates the preparation of } \\
\text { students in the classroom to apply the creative } \\
\text { approach. }\end{array}$ & 4.23 & 1.32 & Strong \\
\hline 33 & 2 & $\begin{array}{l}\text { School build ing has a library equipped with the } \\
\text { latest educational resources. }\end{array}$ & 4.11 & 1.17 & Strong \\
\hline 32 & 3 & $\begin{array}{l}\text { School classrooms has modern technology that } \\
\text { support students learning }\end{array}$ & 4.09 & 1.19 & Strong \\
\hline 35 & 4 & The schoolbuilding has a well-equipped library. & 4.03 & 1.30 & Strong \\
\hline 36 & 5 & The school building offers mental games for & 3.92 & 1.30 & Strong \\
\hline
\end{tabular}




\begin{tabular}{lllllll}
\multicolumn{10}{l}{} & \multicolumn{2}{l}{ students who are creative and talented. } \\
34 & 6 & $\begin{array}{l}\text { The school building has all the services that } \\
\text { support creative education. }\end{array}$ & 3.91 & 1.32 & Strong \\
31 & 7 & $\begin{array}{l}\text { School building has places that allow students to } \\
\text { practice their talents such as painting and design. }\end{array}$ & 3.89 & 1.20 & Strong \\
Overall & & 3.98 & 0.91 & Strong \\
\hline
\end{tabular}

Table 7 shows that the mean of the entire school building theme was 3.98, with a standard deviation of 0.91 , and a strong role. This refers to the quality of the Kuwaiti schools. The Ministry of Education has invested millions of dollars over the past few years in improving the quality of school buildings, facilities, and educational resources. Item 30 that states that "School building facilitates the preparation of students in the classroom to apply the creative approach" scored a mean of $\mathbf{4 . 2 3}$ and standard deviation of $\mathbf{1 . 3 2}$ with a strong role. Item 33 that states that "School building has a library equipped with the latest educational resources" scored a mean of 4.11 and standard deviation of $\mathbf{1 . 1 7}$ with a strong role. Item 32 that states that "School classrooms have modern technology that supports student's creative education" scored a mean of 4.09 and standard deviation of 1.19 with a strong role. These results prove that Kuwaiti schools are well equipped with the required education al resources and facilities that support creative education. These resources and facilities include libraries, laboratories, classrooms, educational technologies, play areas, etc.

The detailed results of the administration theme are presented in Table 8. The mean, standard deviations and rank were analyzed for the administration theme as shown in Table 8 .

Table 8. Mean, standard deviations, rank and school role

\begin{tabular}{|c|c|c|c|c|c|}
\hline No. & Rank & Items & Mean & S.D. & $\begin{array}{l}\text { School } \\
\text { Role }\end{array}$ \\
\hline 10 & 1 & $\begin{array}{l}\text { The school administration clarifies its philosophy of education } \\
\text { and its objectives for all students. }\end{array}$ & 4.56 & 0.89 & Strong \\
\hline 6 & 2 & $\begin{array}{l}\text { The school administration uses team work to support and create } \\
\text { education activities. }\end{array}$ & 4.51 & 0.93 & Strong \\
\hline 1 & 3 & $\begin{array}{l}\text { School administration creates the appropriate organizational } \\
\text { climate. }\end{array}$ & 4.06 & 1.13 & Strong \\
\hline 2 & 4 & $\begin{array}{l}\text { The school administration is concerned with the various } \\
\text { activities of interest to the students. }\end{array}$ & 4.04 & 1.03 & Strong \\
\hline 9 & 5 & School administration provides free speech to students. & 3.80 & 1.08 & Strong \\
\hline 8 & 6 & $\begin{array}{l}\text { School admin istration gives teachers the freedom to apply } \\
\text { creative ideas. }\end{array}$ & 3.73 & 1.05 & Strong \\
\hline 5 & 7 & $\begin{array}{l}\text { The school administration attracts experts in the creativity of } \\
\text { the workshops. }\end{array}$ & 3.26 & 1.27 & Moderate \\
\hline 4 & 8 & $\begin{array}{l}\text { School administration grants moral incentives to creative } \\
\text { students. }\end{array}$ & 3.21 & 1.16 & Moderate \\
\hline 3 & 9 & School administration grants financial incentives to creators. & 3.14 & 1.17 & Moderate \\
\hline 7 & 10 & $\begin{array}{l}\text { School administration uses e-management to develop creative } \\
\text { educational services. }\end{array}$ & 2.90 & 1.34 & Moderate \\
\hline Overall & & & 3.50 & 0.69 & Moderate \\
\hline
\end{tabular}

Table 8 shows that the mean of the administration theme is 3.50 , with a standard deviation of 0.69 and a moderate role. Item 7 that stated "The school administration attracts experts in the creativity of the workshops" scored a mean of $\mathbf{3 . 2 6}$ with standard deviations of $\mathbf{1 . 2 7}$ and a moderate role. Item $\mathbf{8}$ that stated "School administration grants moral incentives to creative students" scored a mean of $\mathbf{3 . 2 1}$ and standard deviation of $\mathbf{1 . 1 6}$ with a moderate role. Item 9 that stated "School admin istration grants financial incentives to creators" scored a mean of $\mathbf{3 . 1 4}$ and standard deviation of $\mathbf{1 . 1 7}$ with a moderate role. Item $\mathbf{1 0}$ that stated "School administration uses e-management to develop creative educational services" scored a mean of $\mathbf{2 . 9 0}$ and a standard deviation of 1.34 with a moderate role. This is referred to traditional administration that most school principals follow in Kuwait. Principals are reluctant to move ahead with the new ideas and approaches that they get trained on, so as to support creative education activities. This is due to the comfort zone that they prefer to stay in and avoid the 
change that needs time and efforts.

The detailed results of Parents and Community theme are presented in Table 9. The mean, standard deviations, and rank were analyzed for the Parents and Community theme as shown in Table 9:

Table 9. Mean, standard deviations, rank and school role

\begin{tabular}{|c|c|c|c|c|c|}
\hline No. & Rank & Item & Mean & S.D. & The Role \\
\hline 45 & 1 & $\begin{array}{l}\text { The family is very interested in creative } \\
\text { education activities. }\end{array}$ & 3.64 & 1.32 & Moderate \\
\hline 39 & 2 & $\begin{array}{l}\text { The family develops the talent of their children } \\
\text { in cooperation with teachers. }\end{array}$ & 3.63 & 1.17 & Moderate \\
\hline 37 & 3 & $\begin{array}{l}\text { The family accepts the creative aspects of their } \\
\text { children. }\end{array}$ & 3.40 & 1.19 & Moderate \\
\hline 42 & 4 & $\begin{array}{l}\text { The family provides the right atmosphere for its } \\
\text { creative and talented children. }\end{array}$ & 3.34 & 1.30 & Moderate \\
\hline 43 & 5 & $\begin{array}{l}\text { The family provides the health care needed for } \\
\text { its creative and talented children. }\end{array}$ & 3.04 & 1.30 & Moderate \\
\hline 40 & 6 & $\begin{array}{l}\text { The community respects creative and talented } \\
\text { people and encourages them to practice } \\
\text { creativity. }\end{array}$ & 3.04 & 1.32 & Moderate \\
\hline 41 & 7 & $\begin{array}{l}\text { The community provides specialized institutions } \\
\text { to support talented and creative people } \\
\text { financially and morally. }\end{array}$ & 2.95 & 1.20 & Moderate \\
\hline 44 & 8 & $\begin{array}{l}\text { The family follows the method of dialogue and } \\
\text { discussion with their children. }\end{array}$ & 2.74 & 1.31 & Moderate \\
\hline 38 & 9 & $\begin{array}{l}\text { The family communicates effectively with the } \\
\text { schooladministration. }\end{array}$ & 2.58 & 1.21 & Moderate \\
\hline Overall & & & 3.15 & 0.96 & Moderate \\
\hline
\end{tabular}

Table 9 shows that the mean for parents and the community theme was 3.15, with a standard deviation of 0.96 and a moderate role. Item 7 that stated "The community provides specialized institutions to support talented and creative people financially and morally" scored a mean of $\mathbf{2 . 9 5}$ and standard deviation of $\mathbf{1 . 2 0}$ with a moderate role. Item 8 that stated "The family follows the method of dialogue and discussion with their children" scored a mean of $\mathbf{2 . 7 4}$ and standard deviation of $\mathbf{1 . 3 1}$ with a moderate role. Item 9 that stated "The family communicates effectively with the school administration" scored a mean of $\mathbf{2 . 5 8}$ and standard deviation of $\mathbf{1 . 2 1}$ with moderate role. These results indicated that parents and community are still not aware of the importance of creative education and creativity for children. Most parents are interested in students' academic achievements rather than creativity or students'critical thinking practices.

Results and Discussion of Question Two: Are there statistical significant differences $(\alpha \leq 0.05)$ in the role of the government schools in creative education of students fro $m$ the point of $v$ iew of primary school teachers in the State of Kuwait due to teachers experience, qualification, and specialization?

To answer this question, the mean, standard deviations, and the multiple analysis of variance (MANOVA) were used as shown in Table 10 below:

Table 10. Mean, standard deviations, and the multiple analysis of variance (MANOVA) for the responses of the sample members due to the variables of experience, academic qualification, and specialization

\begin{tabular}{|c|c|c|c|c|c|c|c|c|}
\hline Variable & Categories & & Adminis trative & Teachers & Curriculum & $\begin{array}{l}\text { School } \\
\text { Building }\end{array}$ & $\begin{array}{l}\text { Parents and } \\
\text { the } \\
\text { Community }\end{array}$ & Total \\
\hline \multirow{5}{*}{ Experience } & \multirow[t]{2}{*}{$(1-5)$} & $\bar{M}$ & 3.50 & 3.88 & 3.48 & 4.02 & 3.09 & 3.51 \\
\hline & & S & 0.71 & 0.80 & 0.94 & 0.91 & 1.02 & 0.76 \\
\hline & \multirow[t]{2}{*}{$6-10$} & M & 3.50 & 4.01 & 3.74 & 3.99 & 3.21 & 3.63 \\
\hline & & $\mathrm{S}$ & 0.69 & 0.60 & 0.79 & 0.87 & 0.90 & 0.58 \\
\hline & $11-15$ & M & 3.50 & 3.97 & 3.63 & 4.00 & 3.42 & 3.83 \\
\hline
\end{tabular}




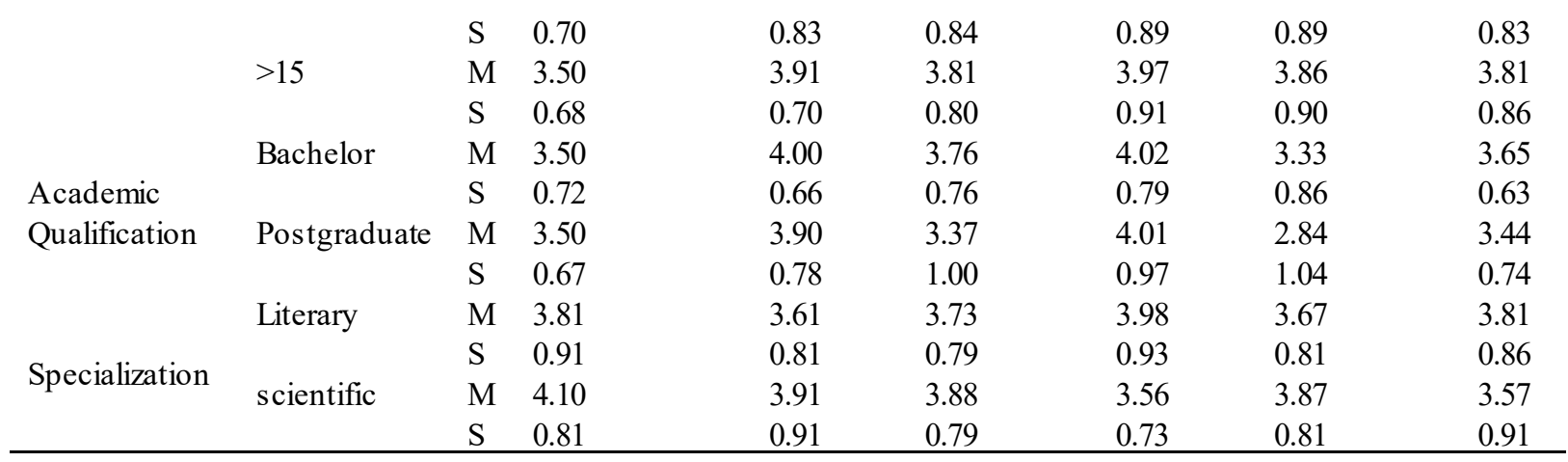

\section{$\mathrm{M}=$ Mean, $\mathrm{S}=$ Standard Deviation}

Table 10 shows an apparent discrepancy in the mean and standard deviations based on the role of the school in the creative education of the students according to the variable of experience for the primary school teachers in the government schools in the State of Kuwait $(\alpha=00.05)$. Also, the table shows differences due to the academic qualification (undergraduate and graduate) and specialization variable (literary and scientific). Multiple analysis of variance (MANOVA) was performed to find out the statistical significance of the differences between the mean. This can be shown in Table 11 below:

Table 11. Multiple analysis of variance (MANOVA) for the responses of the role of the school in creative education of students due to the variables of experience, academic qualification, and specialization

\begin{tabular}{|c|c|c|c|c|c|c|}
\hline Source of Variation & Themes & Sum of Squires & Degree of Freedom & Mean of Squires & F Value & Sig. \\
\hline Experience & Administration & & & & & \\
\hline \multirow{7}{*}{$\begin{array}{l}\text { Wlx. } 0=896 \\
f=0.005\end{array}$} & & 0.000 & 1 & 0.000 & 0.000 & 0.99 \\
\hline & & & & & & \\
\hline & Teachers & 0.129 & 1 & 0.129 & 0.262 & 0.61 \\
\hline & Curriculum & 0.571 & 1 & 0.571 & 0.78 & 0.38 \\
\hline & School building & 0.321 & 1 & 0.321 & 0.67 & 0.37 \\
\hline & Parents and the community & 0.042 & 1 & 0.042 & 0.047 & 0.83 \\
\hline & Total & 0.090 & 1 & 0.090 & 0.197 & 0.66 \\
\hline \multirow{7}{*}{$\begin{array}{l}\text { Qualification holing } 0.096 \\
\mathrm{~F}=0.021\end{array}$} & Administration & 0.000 & 1 & 0.000 & 0.001 & 0.997 \\
\hline & & & & & & \\
\hline & Teachers & 0.206 & 1 & 0.206 & 0.418 & 0.519 \\
\hline & Curriculum & 3.753 & 1 & 3.753 & 5.106 & 0.511 \\
\hline & School building & 4.12 & 1 & 4.12 & 6.12 & 0.612 \\
\hline & Parents and the community & 6.426 & 1 & 6.426 & 7.263 & 0.431 \\
\hline & Total & 1.116 & 1 & 1.116 & 2.445 & 0.120 \\
\hline \multirow{8}{*}{$\begin{array}{l}\text { Specialization } \\
\text { HOLING }=0.012 \\
\mathrm{~F}=0.83\end{array}$} & Administration & 0.075 & 2 & 0.075 & 0.217 & 0.643 \\
\hline & & & & & & \\
\hline & & & & & & \\
\hline & Teachers & 0.169 & 2 & 0.169 & 0.362 & 0.550 \\
\hline & Curriculum & 0.378 & 2 & 0.378 & 0.741 & 0.393 \\
\hline & School building & 0.207 & 2 & 0.207 & 0.414 & 0.523 \\
\hline & Parents and the community & 0.092 & 2 & 0.092 & 0.111 & 0.740 \\
\hline & Total & 0.130 & 2 & 0.130 & 0.417 & 0.512 \\
\hline \multirow[t]{6}{*}{ The error } & Administration & 61.915 & 228 & 0.484 & & \\
\hline & Teachers & 62.959 & 228 & 0.492 & & \\
\hline & Curriculum & 94.085 & 228 & 0.735 & & \\
\hline & School building & 86.20 & 228 & 0.832 & & \\
\hline & Parents and the community & 113.254 & 228 & 0.885 & & \\
\hline & Total & 58.450 & 228 & 0.457 & & \\
\hline Total & Administration & 1691.018 & 265 & & & \\
\hline
\end{tabular}




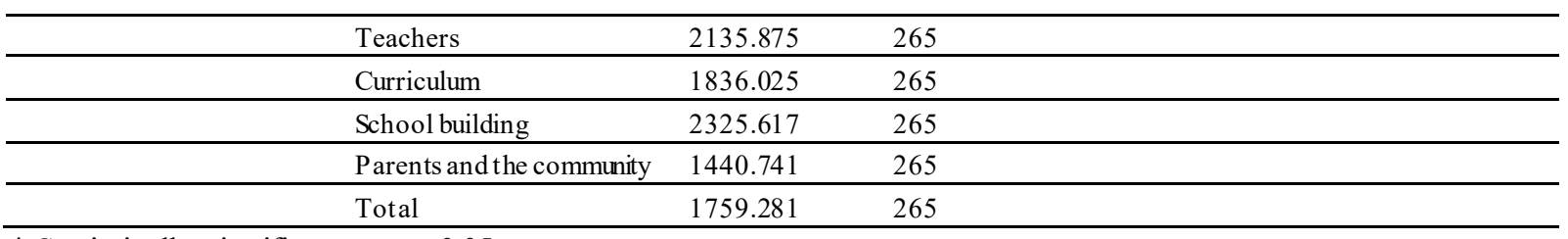

* Statis tically significant $\quad \alpha=0.05$

Table 11 shows that there are no statistically significant differences $(\alpha=0.05)$ due to years of experience, qualification, and specialization for all themes. This result can be attributed to the fact that schools fulfill their duties in creative education in the same way and under the same conditions. This is because these are government schools which have similar educational facilities and resources. In addition, teachers have the same qualification and work condition.

\section{Conclusion and Recommendation}

The findings from the study show that the school role in creative education of students, from the point of view of primary school teachers in the government schools in the State of Kuwait as a whole, was moderate role. Schools have no time to concentrate on creative education and its aspects. More so, school elements focus on the regular daily work and have no real planned activities on creative education. The role of the school elements in creative education varies. On the one hand, teachers believe that they have strong role. On the other hand, they believe that the curriculum, the school building, the school administration, and parents and community have a moderate role.

In the light of the study results, it recommends:

- School curriculum needs to be enhanced with creative education tools and activities.

- Teacher's skills and practices that support creative education practices should be improved.

- School buildings and resources needs to be improved to support creative educational practices.

- Involvement of parents and community in supporting schools' creative education activities.

\section{References}

Abdul, M. (2006). How to create a creative child, Cairo: House of distribution and publishing.

Ajez, F., \& Sheldan, F. (2010). The Role of the school leadership in the development of creativity among secondary school teachers in the Gaza strip governorates from the teachers' point of view. Journal of the Islamic University, 18(1), 1-37.

Al-Asaf, J. (2013). The attitudes of Social studied teachers toward the development of creative thinking skills among the students of the upper elementary stage in the directorate of the third Aman Education. Journal of Islamic University, 21(1), 269-292.

Bovetin, F. (2012). The contribution of kind ergarten principals in the development of educational creativity of teachers and its relation to organizational loyalty from the point of view of teachers in the State of Kuwait, Unpublished Master dissertation, Middle East University, Amman

Diab, S. (2005). Obstacles to creativity development. The 2nd Conference of the Faculty of Education, the Islamic University of Gaza, November 5-7.

Enezi, O. (2008). The level of ad min istrative innovation among school principals in the north Saudi Arabia from the point of view of teachers and educational supervisors. Unpublished Master dissertation, Yarmouk University, Jordan.

Huwailah, A., \& A1-Huwailah, M. (2009). The degree of practice of principals of secondary schools in the Ahmadi educational area of the behaviors of achieving Administration innovation. Journal of the Union of Arab Universities, (53), 507-545.

Kandemir, M., \& GÜR, H. (2006). Creativity training in problem solving. Balikesir University, Turkey.

Mshrfe, E. (2005). Teaching creative thinking to kindergarten child, Cairo: Egyptian Lebanese House for publishing.

Ozmen, F., \& Muratoglu, V. (2010). The competency levels of school principals in implementing knowledge management strategies from the views of principals and teachers according to gender variable. Procedia 
Social and Behavioral Sciences, 2(20), 5370-5376.

Robina, S. (2010). An Investigation into the factors or inhibiting primary school children's creativity in Pakistan. A thesis submitted to the University of Birmingham for the degree of PhD, University of Birmingham: UK.

Rojanapanich, P., \& Pimpa, N. (2011). Creative education, globalization and social imaginary. Creative Education, 2(4).

Sharari, A. (2005). Obstacles to creativity among teachers and secondary school teachers in Al-Jouf Region: Saudi Arabia, from their Point of View, Unpublished Master Dissertation, University of Jordan: A mman, Jordan.

Sharari, A. (2008). Role of government schools principals in developing creativity among teachers in A1-Jouf Region in Saudi Arabia from the perspective of the teachers themselves, Unpublished PhD thesis, Yarmouk University, Irbid, Jordan.

Subaihi, M. (2006). The obstacles that limit the process of artistic creativity at the teacher of art education, Unpublished Master Dissertation, Umm Al-Qura University, Makkah, Saudi Arabia.

Trifonova, A. (2012). Learner centered design approach, impacts on teacher's' creativity. University of Barcelona, Spain.

W fry, R. (2006). The Relationship between principals innovative style and teacher's perception of principals effectiveness. Dissertation Abstract International, 456(7), 3100.

Yahya, S. (2007). Admin istration creativity in government high schools for girls in Madinah. Educational Journal, 21(82), 5-112.

\section{Copyrights}

Copyright for this article is retained by the author(s), with first publication rights granted to the journal.

This is an open-access article distributed under the terms and conditions of the Creative Commons Attribution license (http://creativecommons.org/licenses/by/4.0/). 